Table 1. Proportions and Rates of LDA/sustained LDA by Treatment Group

\begin{tabular}{|c|c|c|c|c|c|c|c|c|}
\hline \multirow[b]{2}{*}{ Pts achieving $\mathrm{CDAI} \leq 10$} & \multirow[b]{3}{*}{ \# of visits } & \multirow[b]{3}{*}{ Category } & \multicolumn{3}{|c|}{ csDMARD-IR pts ${ }^{\mathrm{a}}$} & \multicolumn{3}{|c|}{ bDMARD-IR pts ${ }^{\mathrm{b}}$} \\
\hline & & & \multirow{2}{*}{$\begin{array}{l}\text { PBO } \\
\mathrm{N}=228\end{array}$} & \multirow{2}{*}{$\begin{array}{c}\text { Bari } \\
2 \mathrm{mg} \\
\mathrm{N}=229\end{array}$} & \multirow{2}{*}{$\begin{array}{c}\text { Bari } \\
4 \mathrm{mg} \\
\mathrm{N}=227\end{array}$} & \multirow{2}{*}{$\begin{array}{l}\text { PBO } \\
\mathrm{N}=176\end{array}$} & \multirow{2}{*}{$\begin{array}{c}\text { Bari } \\
2 \mathrm{mg} \\
\mathrm{N}=174\end{array}$} & \multirow{2}{*}{$\begin{array}{c}\text { Bari } \\
4 \mathrm{mg} \\
\mathrm{N}=177\end{array}$} \\
\hline Time & & & & & & & & \\
\hline \multirow[t]{4}{*}{ Original study (24 wks) } & $\geq 1$ & $\%$ & 44.7 & 60.7 & 65.6 & 26.7 & 39.7 & 48.6 \\
\hline & & i-rate & 12.06 & 18.79 & 21.50 & 6.36 & 10.08 & 13.38 \\
\hline & $\geq 2$ & $\%$ & 32.0 & 48.5 & 52.9 & 15.9 & 28.7 & 35.6 \\
\hline & & i-rate & 7.32 & 12.11 & 13.95 & 3.50 & 6.42 & 8.29 \\
\hline \multirow[t]{4}{*}{ Original study + LTE } & $\geq 1$ & $\%$ & 56.6 & 70.7 & 71.4 & 39.8 & 47.7 & 53.1 \\
\hline & & i-rate & 4.93 & 8.14 & 9.40 & 2.85 & 3.81 & 4.85 \\
\hline & $\geq 2$ & $\%$ & 48.2 & 61.6 & 61.2 & 27.8 & 39.1 & 44.1 \\
\hline & & i-rate & 3.41 & 5.33 & 5.78 & 1.66 & 2.57 & 3.13 \\
\hline
\end{tabular}

Pts were defined as responders if they met the response criterion within the stated time frame, prior to any rescue or discontinuation. $\%=$ percent of pts meeting response criteria; $\geq 2=$ at least 2 consecutive visits with $\mathrm{CDAl} \leq 10$; i-rate $=$ exposure-adjusted incidence rate $(\% \mathrm{pts} / \mathrm{month}) ; \mathrm{N}$ $=$ number of randomised and treated pts; $\mathrm{PBO}=$ placebo treated pts in original study, Bari $4 \mathrm{mg}$ treated pts in LTE. ${ }^{\mathrm{a}} \mathrm{RA}-\mathrm{BUILD},{ }^{\mathrm{b}} \mathrm{RA}-\mathrm{BEACON}$.

[2] Genovese M et al. N Engl J Med 2016; 374(13):1243-52.

Disclosure of Interest: J. Curtis Grant/research support from: Abbvie, Amgen, BMS, Corrona, Eli Lilly and Company, Janssen, Myriad, Pfizer, Roche/Genentech, UCB, Consultant for: Abbvie, Amgen, BMS, Corrona, Eli Lilly and Company, Janssen, Myriad, Pfizer, Roche/Genentech, UCB, A. Kavanaugh Consultant for: Eli Lilly and Company, D. van der Heijde Consultant for: Abbvie, Amgen, Astellas, Astra-Zeneca, BMS, Boeringer Ingelheim, Celgene, Daiichi Sankyo, Eli Lilly and Company, Galapagos, Gilead, Janssen, Merck, Novartis, Pfizer, Regeneron, Roche, Sanofi-Aventis, UCB, Employee of: Director of Imaging Rheumatology bv, D. Muram Employee of: Eli Lilly and Company, J. Alam Employee of: Eli Lilly and Company, S. Beattie Employee of: Eli Lilly and Company, J. Smolen Grant/research support from: Abbvie, Janssen, Eli Lilly and Company, MSD, Pfizer, Roche, Consultant for: Abbvie, Amgen, Astra-Zeneca, Astro, BMS, Celgene, Celltrion, Chugai, Gilead, Glaxo, ILTOO, Janssen, Eli Lilly and Company, Medimmune, MSD, Novartis-Sandoz, Pfizer, Roche, Samsung, Sanofi-Aventis, UCB, Speakers bureau: Abbvie, Amgen, Astra-Zeneca, Astro, BMS, Celgene, Celltrion, Chugai, Gilead, Glaxo, ILTOO, Janssen, Eli Lilly and Company, Medimmune, MSD, Novartis-Sandoz, Pfizer, Roche, Samsung, Sanofi-Aventis, UCB

DOI: 10.1136/annrheumdis-2017-eular.1339

\section{FRI0090 ANALYSIS OF NEUTROPHILS, LYMPHOCYTES, AND PLATELETS IN POOLED PHASE 2 AND PHASE 3 STUDIES OF BARICITINIB FOR RHEUMATOID ARTHRITIS}

J. Kremer ${ }^{1}$, T.W.J. Huizinga ${ }^{2}$, L. Chen ${ }^{3}$, C.G. Saifan ${ }^{3}$, M. Issa ${ }^{3}$, S.L. Witt ${ }^{3}$, ${ }_{\text {C.D. Walls }}{ }^{3}$, I. de la Torre ${ }^{3}$. 'Albany Medical College, New York, United States; ${ }^{2}$ Leiden University Medical Center, Leiden, Netherlands; ${ }^{3}$ Eli Lilly and Company, Indianapolis, United States

Background: Rheumatoid arthritis (RA) is associated with increased neutrophil levels $^{1}$ and platelet ${ }^{2}$ counts and decreased lymphocyte levels. ${ }^{1,3}$ Baricitinib (bari) is a selective and reversible Janus kinase (JAK)1/JAK2 inhibitor in development for patients (pts) with moderate to severe RA. ${ }^{4}$

Objectives: To characterize changes in absolute neutrophil counts (ANC), absolute leukocyte counts (ALC), and platelet counts following once daily oral administration of bari.

Methods: Data were pooled from 6 placebo-controlled phase 2 and 3 studies of bari $(2$ and $4 \mathrm{mg}$ ). Changes in ANC, ALC, and platelets were evaluated for up to 52 weeks (wks) including data from a long-term extension study. Reversibility was evaluated in a subgroup of pts who discontinued treatment by wk 24 .

Results: Mean ANC decreased within 1 month of administration of bari, followed by stabilization and an increase to baseline after treatment discontinuation (Figure 1). ANC $<1000$ cells $/ \mathrm{mm}^{3}$ were reported in $<1 \%$ of pts, and 2 bari-treated pts $(0.1 \%)$ reported permanent discontinuation of study drug due to neutropenia. Incidence of neutropenia was not associated with higher risk of overall or serious infections (Table 1).

Mean ALC increased within 1 month of bari administration and then decreased to
Figure 1: Longitudinal Profiles of Neutrophils, Lymphocytes, and Platelets ween

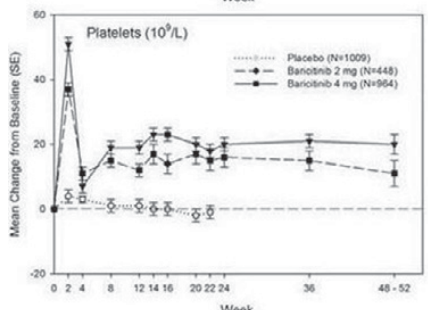

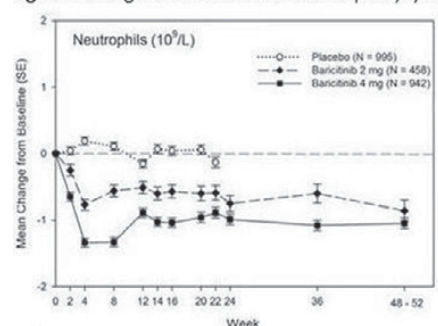
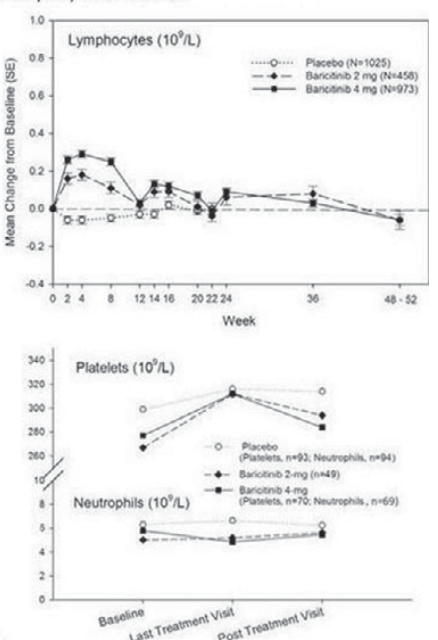

baseline level in wks 12 to 24 (Figure 1). Lymphopenia appeared to be associated with slightly higher rate of overall infections (Table 1).

Mean platelet counts increased to peak at wk 2, returned towards baseline, stabilized over time, and returned to baseline after treatment discontinuation (Figure 1). Permanent study drug discontinuations from thrombocytosis occurred in 2 bari-treated pts $(0.1 \%)$. No clear association between platelet increase and thromboembolic events was observed.

Conclusions: Treatment with bari was associated with a decrease in ANC and an increase in ALC and platelets, which stabilized over time and returned to baseline with prolonged treatment (ALC) or treatment discontinuation (ANC and platelets). No associations between ANC decrease and infections or between thrombocytosis and thromboembolic events were observed.

References:

[1] Schulze-Koops H et al. Rheumatology. 2017;56(1):46-57.

[2] Farr M et al. Ann Rheum Dis. 1983;42(5):545-549.

[3] Symmons DP et al. J R Soc Med. 1989:82:462-463.

[4] Fridman JS et al. J Immunol. 2010;184:5298-5307.

Disclosure of Interest: J. Kremer Grant/research support from: Abbvie, Genentech, Eli Lilly and Company, Novartis, Pfizer, Consultant for: Abbvie, Amgen, BMS, Genentech, GSK, Eli Lilly and Company, Novartis, Pfizer, Employee of: Corrona, Speakers bureau: Genentech (non-promotional), T. W. J. Huizinga Grant/research support from: Eli Lilly and Company, Pfizer, Consultant for: Eli Lilly and Company, Pfizer, Speakers bureau: Eli Lilly and Company, Pfizer, L. Chen Employee of: Eli Lilly and Company, C. Saifan Employee of: Eli Lilly and Company, M. Issa Employee of: Eli Lilly and Company, S. Witt Employee of: Eli Lilly and Company, C. Walls Employee of: Eli Lilly and Company, I. de la Torre Employee of: Eli Lilly and Company

DOI: 10.1136/annrheumdis-2017-eular.1325

\section{FRI0091 PATIENT-PROVIDER DISCORDANCE MAY BE ASSOCIATED WITH INCREASED RISK OF SUBSEQUENT FLARES IN PATIENTS WITH RHEUMATOID ARTHRITIS}

E. Myasoedova, C.S. Crowson, K. McCarthy-Fruin, E.L. Matteson, J.M. Davis III. Rheumatology, Mayo Clinic College of Medicine and Science, Rochester, MN, United States

Background: Patient-provider discordance in assessment of disease status has been linked to lower patient satisfaction with potential implications on patient compliance and outcomes of care. Global assessment (GA) of disease activity in rheumatoid arthritis (RA) is discordant between patient and provider in about one third of cases. Prospective studies evaluating the implications of patient-provider discordance on RA disease course are lacking.

Abstract FRI0090 - Table 1. Infection by Worst Neutropenia and Lymphopenia CTCAE Grade in Placebo-Controlled Period up to Week 24

\begin{tabular}{|c|c|c|c|c|c|c|}
\hline & \multicolumn{3}{|c|}{ Placebo } & \multicolumn{3}{|c|}{ Baricitinib 4-mg } \\
\hline & Total Pts & Pts (\%) with Overall Infection & Pts (\%) with Serious Infection & Total Pts & Pts (\%) with Overall Infection & Pts (\%) with Serious Infection \\
\hline \multicolumn{7}{|l|}{ Neutropenia CTCAE Grade } \\
\hline $0\left(\geq 2 \times 10^{9} \mathrm{cells} / \mathrm{L}\right)$ & 985 & $279(28.3)$ & $16(1.6)$ & 853 & $313(36.7)$ & $13(1.5)$ \\
\hline $1\left(<2\right.$ and $\geq 1.5 \times 10^{9}$ cells/L) & 34 & $10(29.4)$ & 0 & 74 & $32(43.2)$ & $1(1.4)$ \\
\hline $2\left(<1.5\right.$ and $\geq 1.0 \times 10^{9}$ cells $\left./ L\right)$ & 9 & 0 & 0 & 27 & $11(40.7)$ & 0 \\
\hline $3\left(<1.0\right.$ and $\geq 0.5 \times 10^{9}$ cells $\left./ \mathrm{L}\right)$ & 1 & $1(100.0)^{1}$ & 0 & 3 & $1(33.3)^{2}$ & 0 \\
\hline $4\left(<0.5 \times 10^{9} \mathrm{cells} / \mathrm{L}\right)$ & 0 & 0 & 0 & 0 & 0 & 0 \\
\hline \multicolumn{7}{|l|}{ Lymphopenia CTCAE Grade } \\
\hline $0\left(\geq 1.1 \times 10^{9} \mathrm{cells} / \mathrm{L}\right)$ & 710 & $201(28.3)$ & $12(1.7)$ & 704 & $246(34.9)$ & $8(1.1)$ \\
\hline $1\left(<1.1\right.$ and $\geq 0.8 \times 10^{9}$ cells $\left./ \mathrm{L}\right)$ & 233 & $65(27.9)$ & $2(0.9)$ & 205 & $81(39.5)$ & $2(1.0)$ \\
\hline $2\left(<0.8\right.$ and $\geq 0.5 \times 10^{9}$ cells $\left./ L\right)$ & 103 & $30(29.1)$ & $1(1.0)$ & 71 & $31(43.7)$ & $3(4.2)$ \\
\hline $3\left(<0.5\right.$ and $\geq 0.2 \times 10^{9}$ cells $\left./ L\right)$ & 13 & $3(23.1)$ & $1(7.7)$ & 8 & $4(50.0)$ & $1(12.5)$ \\
\hline $4\left(<0.2 \times 10^{9} \mathrm{cells} / \mathrm{L}\right)$ & 0 & 0 & 0 & 0 & 0 & 0 \\
\hline
\end{tabular}

CTCAE $=$ common terminology criteria for adverse events; pts = patients. ${ }^{1}$ Upper respiratory tract; ${ }^{2}$ Pharyngitis. 